\title{
AKTIVITAS PEMASARAN PRODUK BANK PADA PT. BANK PERKREDITAN RAKYAT (BPR) CEMPAKA MITRA NAGARI PADANG
}

\author{
Vista Duhwi Putri, Romi Susanto \\ Akademi Keuangan dan Perbankan "Pembangunan" (AKBP) Padang \\ vistaduhwiputri28@gmail.com
}

\begin{abstract}
The purpose of this study was to find out how the marketing activities of bank products of PT. BPR Cempaka Mitra Nagari Padang. The data used in this study is to directly interview the interested parties. The data collection techniques are by field studies and library studies. From research and discussion it can be concluded that the marketing activities carried out can be planned and directed so that the bank implements policies in collecting and channeling funds by creating good quality storage products, set interest rates in accordance with applicable regulations and strategic operational places, and facilitate the community by providing services owned by the bank
\end{abstract}

Keywords : marketing activities, funds raising, funds distribution, and bank services

\section{PENDAHULUAN}

Dunia perbankan merupakan salahsatu institusi yang sangat berperan penting dalam bidang perekonomian suatu Negara (khususnya dibidang pembiayaan, perekonomian dan pembangunan). Perbankan adalah segala sesuatu yang menyangkut tentang bank, kelembagaan, kegiatan usaha, serta cara dan proses dalam melaksanakan kegiatan usahanya. Menurut Undang-Undang RI No.10 Tahun 1998 tentang perbankan, Bank adalah badan usaha yang menghimpun dana dari masyarakat dalam bentuk simpanan dan menyalurkannya kepada masyarakat dalam bentuk kredit dana tau bentuk-bentuk lainnya dalam rangka meningkatkan taraf hidup rakyat banyak.

Dengan makin ketatnya persaingan pasar perbankan, dipaksa saat ini harus melakukan pemasaran dengan mendatangi calon nasabah baik di rumah maupun di tempat kerja dan disertai dengan promosi di media-media (Sinuhaji, 2010). Standar layanan tersebut adalah Tersedianya sarana dan prasarana yang baik. ROA mengutamakan kemampuan pada perusahaan dengan memperoleh earning dalam mengoperasikan perusahaan (Chasanah, 2016). Pemasaran merupakan salah satu aspek yang sangat penting dalam memenuhi kebutuhan dan keinginan nasabahnya terhadap produk perbankan, baik itu dalam produk simpanan (deposito, tabungan, giro), kredit atau jasa-jasa bank lainya. Penyediaan produk bank harus dilakukan dengan perencanaan yang matang, untuk jangka pendek maupun jangka panjang.

Dengan cara mengetahui keinginan dan kebutuhan nasabah yang memudahkan bank dalam melakukan strategi guna merebut hati nasabah. Strategi 
yang dilakukan meliputi penentuan strategi produk, strategi harga, strategi lokasi dan strategi promosi strategi ini dikenal dengan nama bauran pemasaran (marketing mix). Bank merupakan sebagai lembaga pelantara keuangan (financial intermediaries) yang menyalurkan dana dari pihak yang berkelebihan dana kepada pihak yang membutuhkan dana pada waktu yang ditentukan. Dana-dana yang digunakan sebagai alat operasional suatu bank bersumber dari modal sendiri yang berasal dari pihak bank, pinjaman dari pihak luar dan berupa simpanan dari pihak masyarakat (tabungan, deposito, giro). Sedangkan dana yang dihimpun oleh bank harus disalurkan kembali kepada masyarakat dalam bentuk kredit. Karena Pemberian kredit merupakan aktivitas bank yang paling utama dalam menghasilkan keuntungan, tetapi resiko terbesar dalam bank juga bersumber dari pemberian kredit. Oleh karna itu bank harus berhati-hati dalam menempatkan dana dalam bentuk kredit.

Bank Perkreditan Rakyat mempunyai kegiatan usaha yang lebih terbatas dibanding dengan bank umum. Bank Perkreditan Rakyat hanya menerima simpanan dalam bentuk deposito berjangka, tabungan dan bentuk lain yang dipersamakan dengan itu dan tidak menerima penghimpunan danadalam bentuk giro. Untuk itu BPR memasarkan produknya agar produk tersebut diminati oleh masyarakat. Keberhasilan suatu bank dalam menguasai pasar sangat tergantung pada pilihan suatu strategi dan kebijaksanaan serta aktivitas pemasaran yang lebih efektif. Demikian halnya pada PT. BPR Cempaka Mitra Nagari Padang mengantisipasi era globalisasi dan perdagangan bebas, memberikan inovasi dalam menghimpun dan menyalurkan dana pada masyarakat lewat beragam produkproduk yang di pasarkan.

Berdasarkan uraian tersebut, maka tujuan penelitian ini yaitu untuk mengetahui bagaimana permasalahan aktivitas pemasaran produk bank pada PT. Bank Perkreditan Rakyat Cempaka Mitra Nagari Padang.

\section{METODE PENELITIAN}

Metode penelitian yang digunakan yaitu bersifat deskriptif menggunakan analisa kualitatif, dimana penelitian dilakukan dengan menganalisa dan menjelaskan proses penghimpunan dana masyarakat dan pemberian kredit yang ada pada PT. Bank Perkreditan Rakyat Cempaka Mitra Nagari Padang.

\section{HASIL DAN PEMBAHASAN}

\section{Bauran Pemasaran Yang Dilakukan Oleh PT. BPR. Cempaka Mitra Nagari Padang}

Agar penghimpunan dan penyaluran dana itu meningkat dari tahun ke tahun PT. BPR. Cempaka Mitra Nagari menerapkan kegiatan pemasaran baik yang terencana dan terarah. Untuk melihat tingkat keberhasilan pemasaran yang telah dilakukan suatu bank dapat kita liat dari segi marketing mixyang dijalankannya. Karena marketing mixitu merupakan suatu perangkat yang akan menentukan tingkat keberhasilan pemasaran dan semua itu ditujukan untuk memberikan kepuasan nasabah yang ada maupun nasabah yang potensial. 
PT. BPR.Cempaka Mitra Nagari menggunakan kebijaksanaan pemasaran yang terdiri dari kebijaksanaan produk, harga, promosi, tempat (distribusi), orang (karyawan), proses (alur kerja), layanan pelanggan.

\section{A. Produk Penghimpunan Dana Masyarakat}

a. Tabungan

Bentuk tabungan yang dihimpun oleh PT. BPR Cempaka Mitra

Nagari terdiri dari:

1) Tabungan Cempaka

Tabungan Cempaka adalah tabungan khusus untuk nasabah kredit dan karyawan nomor rekeningnya diawali dengan 330.0.besar bunga tabungan di BPR Cempaka Mitra Nagari yaitu sebesar 2\% dan biaya administrasinya sebesar 1.500 per bulan.

2) Tabungan Mitra Nagari

Tabungan Mitra Nagari adalah tabungan nasabah umum, tabungan ini dapat ditarik sewaktu-waktu. Setoran awal nya sebesar Rp.25.000,-

3) Tabungan Qurban

Tabungan qurban adalah tabungan untuk qurban.Tabungan ini tidak ada dikenakan biaya administrasi, bunga nya $2 \%$ per tahun. Setoran awal nya sebesar Rp.25.000,- dan setoran maksimal nya sebesar Rp.50.000,-

4) Tabungan Pionir (Tabungan Pelajar)

Tabungan Pionir adalah tabungan khusus untuk pelajar yang belum mempunyai KTP.Tabungan pelajar ini di tujukan untuk anak TK, serta anak SD. Tabungan pelajar ini tidak dikenakan biaya administrasi dan bunga nya sebesar 2\%.Tabungan ini dapat di tarik sewaktu-waktu setoran awal nya sebesar Rp.5.000,- setoran maksimal nya sebesar Rp.15.000,-

5) Tabungan SIMPEL

Yaitu tabungan untuk siswa pelajar atau anak-anak yang berusia di bawah 17 tahun atau belum memiliki KartuTanda Penduduk (KTP) yang diterbitkan secara Nasional oleh Bank Indonesia dengan fitur yang menarik dalam rangka mengedukasi keuangan untuk budaya menabung sejak dini. Tingkat suku bunga yang diberikan $2 \%$ per tahun.

Sistem pelayanan tabungan dengan melakukan penyetoran dan penarikan dapat dilakukan langsung dikantor PT. BPR Cempaka Mitra Nagari Padang atau di jemput dan di antar oleh petugas lapangan (Marketing) hal ini merupakan salah satu keunggulan dari BPR, selain itu setiap tabungan juga bebas biaya administrasi setiap bulannya.

Proses pembukaan rekening tabungan PT. BPR Cempaka Mitra Nagari Padang adalah :

a. Calon nasabah datang menghadap petugas dan menyatakan maksudnya untuk membuka rekening tabungan baru.

b. Petugas menjelaskan bentuk tabungan yang ada berikut dengan persyaratannya dan selanjutnya meminta persetujuan calon nasabah jika setuju nasabah diminta untuk mengisi permohonan yang telah 
disediakan PT. BPR Cempaka Mitra Nagari Padang dan menyerahkan kartu identitas untuk nantinya dicatat pada speciment.

c. Calon nasabah menyatakan persetujuannya, mengisi blanko permohonan dan menyerahkan kartu identitasnya kepada petugas untuk dicatat.

d. Petugas memeriksapengisian blanko permohonan dan keabsahan kartu identita nasabah. Selanjutnya mempersiapkan dan meminta nasabah untuk mencantumkan contoh tanda tangannya pada speciment.

e. Nasabah mencantumkan contoh tanda tangannya pada blanko speciment dan menyerahkannya kembali kepada petugas.

f. Petugas mmeriksa kembali pencantuman tanda tangan nasabah yang bersangkutan dan mencatatkan data kartu identitas nasabah yang bersangkutan pada blanko speciment tersebut, menyiapkan nomor rekening dan buku tabungan baru untuk nasabah yang bersangkutan dan meminta nasabah untuk melakukan penyetoran setoran awal melalui teller dengan menggunakan slip setoran.

g. Nasabah menyetorkan setoran awalnya melalui kasir dengan menggunakan slip penyetoran.

h. Teller menerima setoran dari nasabah sesuai dengan yang tercantum pada slip setoran, mencantumkan parafnya pada slip setoran dan menyerahkan kembali slip setoran kepada petugas.

i. Petugas mencatatkan setoran nasabah tersebut pada buku tabungan melalui komputer dan kemudian memaraf dan menyerahkan berkas pembukaan rekening baru tersebut (permohonan, kartu identitas nasabah, speciment, buku tabungan dan slip setoran) kepada pejabat untuk meminta persetujuan.

j. Pejabat memeriksa berkas di atas dan jika sudah betul langsung memberikan persetujuan dengan mencantumkan tanda tangannya pada speciment dan permohonan nasabah. Kemudian menyerahkan kembali berkas dimaksud kepada petugas.

k. Petugas menyerahkan buku tabungan dan kartu identitas kepada nasabah/penabung, menyimpan berkas buku tabungan baru dan mengumpulkan slip setoran untuk nantinya direkap dan dijilid sebagai bukti pembukuan pada hari yang sama.

b. Deposito

Adalah simpanan yang penarikannya dapat dilakukan dalam jangka waktu tertentu. Adapun fasilitas yang dapat diperoleh nasabah adalah :

a). Deposito dalam rupiah.

b). Bunga deposito bersaing.

c). Bunga dapat diambil setiap bulan atau dipindahbukukan ke rekening tabungan.

d). Jangka waktu dapat dipilih antara 1 bulan, 3 bulan, 6 bulan, 12 bulan, 24 bulan. Deposito juga dapat diperpanjang secara otomatis. 
Persyaratan pembukaan rekening Deposito Berjangka PT. BPR Cempaka Mitra Nagari Padang adalah :

a). Mengisi permohonan.

b). Menyerahkan photocopy KTP/SIM.

Proses pembukaan rekening Deposito Berjangka PT. BPR Cempaka Mitra Nagari Padang adalah :

a. Nasabah datang menemui petugas dan menyampaikan maksudnya untuk membuka rekening deposito baru.

b. Petugas menjelaskan ketentuan dan syarat-syarat pembukaan deposito yang ada dan meminta nasabah untuk menentukan pilihan serta mengisi dan menanda tangani blanko permohonan.

c. Nasabah setuju dan menentukan pilihannya. Selanjutnya mengisi dan menandatangani blanko permohonan dan menyerahkan kembali kepada petugas.

d. Petugas memeriksa pengisian balanko dan jika sudah benar maka nasabah mendatangi speciment dan menyerahkan kartu identitasnya untuk dicatat pada speciment tersebut.

e. Nasabah mendatangi blanko speciment dan menyerahkan kembali kepada petugas beserta kartu identitas.

f. Petugas mencatat kartu identitas nasabah yang bersangkutan kepada speciment, menyiapkan bilyet deposito dan meminta nasabah menyetorkan uang depositonya kepada kasir.

g. Nasabah mnenyetorkan uang depositonya kepada Teller.

h. Teller menghitung uang setoran dan mencocokkan jumlahnya dengan slip setoran dan nominal deposito pada bilyet itu, jika sudah cocok mencantumkan parafnya pada slip dan bilyet kemudian menyerahkan kembali bilyet itu berikut slip setoran kepada petugas.

i. Petugas mencatatkan pembukaan deposito pada buku register deposito dan aplikasi/program komputer, sesuai menunya. Setelah itu menyerahkan berkas deposito yang dimaksud yang berisikan, permohonan, speciment, kartu identitas nasabah, slip setoran dan bikyet deposito, kepada pejabat yang berwenang untuk diberikan persetujuan.

j. Pejabat bank yang berwenang memeriksa keabsahan dan pemenuhan persyaratan formal pembukaan deposito baru dan jika telah benar langsung menandatangani bilyet a.n. PT. BPR Cempaka Mitra Nagari Padang dan menyerahkan berkas itu kembali kepada petugas.

k. Petugas menyerahkan kembali bilyet deposito asli dan kartu identitas kepada nasabah, menyimpan lemabar kedua bilyet untuk bukti pembukuan dan lembar ketiga untuk arsip. 
Untuk melihat perkembangan penghimpunan dana PT. BPR

Cempaka Mitra nagari Padang secara terperinci dapat dilihat pada tabel 1 di bawah ini:

Tabel 1

Perkembangan Penghimpunan Dana Masyarakat

PT. Bank Perkreditan Rakyat Cempaka Mitra Nagari Padang

Tahun 2014-2018 (Dalam Rupiah)

\begin{tabular}{|c|c|c|}
\hline \multirow{2}{*}{ Tahun } & \multicolumn{2}{|c|}{ Penghimpunan Dana Masyarakat } \\
\cline { 2 - 3 } & Jumlah (Rp) & Perubahan (\%) \\
\hline 2014 & 9.662 .989 & - \\
\hline 2015 & 7.473 .947 & $(2265)$ \\
\hline 2016 & 7.030 .751 & $(5.92)$ \\
\hline 2017 & 6.872 .750 & $(2.24)$ \\
\hline 2018 & 6.320 .653 & $(8.03)$ \\
\hline
\end{tabular}

Sumber :PT. BPR Cempaka Mitra Nagari Padang

Berdasarkan table 1 Penghimpunan dana masyarakat pada PT. BPR Cempaka Mitra Nagari Padang dari tahun 2014 sampai 2018 trend cenderung menurun pada tahun 2014-2015 sebesar Rp. 2.189.022,- atau 22,65\% begitu juga pada tahun 2015-2016 sebesarRp. 443.196,- atau 5,92\% kemudian pada tahan 2016-2017 sebesar Rp. 158.001,- atau 2,24\% kemudian juga pada tahun 2017-2018 sebesar Rp. 552.097,- atau $8,03 \%$ hal ini disebabkan oleh penurunan nilai tabungan dan deposito, penurunan tingkat tabungan masyarakat dari tahun 2014-2015 sebesar Rp. 111.022 atau 7,72\% pada tahun 2015-2016 sebesar Rp. 37.696,- atau 2,84\% kemudian pada tahun 2016-1017 sebesar Rp. 19Rp.7.097,- atau $15,395 \%$ penurunan deposito masyarakat tahun 2014-2015 sebesar Rp. 2.078.000,- atau 25,26\% begitu juga pada tahun 2015-2016 sebesar 405.500,- atau 6,59\% kemudian pada tahun 2016-2017 sebesar 150.000,atau 2,615\% kemudian juga pada tahun 2017-2018 sebesar Rp. 355.000,atau 6,34\% secara umum menurunnya jumlah penghimpunan dana masyarakat PT. BPR Cempaka Mitra Nagari Padang disebabkan karna masyarakat membutuhkan banyak biaya untuk membeli perlengkapan sekolah dan di waktu lebaran masyarakat lebih memilih belanja untuk keperluan lebaran dari pada menabung.

\section{B. Penyaluran Dana}

Jenis-jenis produk penyaluran dana/kredit yang disalurkan PT. BPR Cempaka Mitra Nagari adalah sebagai berikut :

1) Kredit Modal Kerja

Adalah kredit yang diberikan oleh bank kepada nasabahnya untuk keperluan sebagai modal kerja untuk usahanya, yang mana kredit ini diberikan kepada nasabah yang ingin membuka suatu usaha tetapi tidak mempunyai modal dasar untuk memulai usahanya tersebut.Disini bank memberikan kredit sesuai dengan kebutuhan nasabah.

2) Kredit Investasi

Kredit yang diberikan bank kepada para nasabahnya yang mana kredit ini dipergunakan untuk keperluan sebagai penanaman modal oleh 
para nasabahnya, kredit tersebut ditujukan untuk keperluan perbaikan atau penambahan barang-barang modal kerja beserta fasilitas-fasilitas lainnya. Misalnya untuk membangun gudang, pabrik, membeli atau mengganti mesin-mesin dan lain sebagainya.

3) Kredit Konsumsi

Kredit yang diberikan oleh bank kepada para nasabahnya atau debitur yang mana kredit ini diperlukan untuk keperluan konsumsi atau keperluan untuk mencukupi kebutuhan/tuntutan hidup sehari-harinya yang belum dapat terpenuhi dengan penghasilan yang diperolehnya, seperti keperluan untuk menyekolahkan anak-anaknya ke jenjang pendidikan yang lebih tinggi serta kebutuhan-kebutuhan lainnya yang juga akan meningkatnya pertumbuhan ekonomi.

Proses pemberian kredit pada PT. BPR Cempaka Mitra Nagari Padang adalah :

a. Calon debitur mengajukan permohonan kredit kepada PT. BPR Cempaka Mitra Nagari Padang dengan persyaratan yang harus dipenuhi adalah sebagai berikut :

1) Mempunyai jaminan kredit berupa :

a) Kendaraan bermotor roda dua.

b) Kendaraan bermotor roda empat.

c) Sertifikat tanah hak milik.

d) Hak sewa toko pada Pemda.

e) SK bagi Pegawai Negeri Sipil.

2) Mempunyai usaha yang sedang berjalan (minimal 6 bulan), syarat ini ditujukan untuk kredit investasi dan kredit modal kerja.

b. Bank mencatat permohonan kredit ke dalam buku register dan meneliti surat permoohonan kredit beserta kebenaran dokumendokumen yang diserahkan calon debitur.

c. Accoun Officer melakukan kegiatan pencarian informasi selengkaplengkapnya dari berbagai sumber mengenai calon debitur, informasi tersebut diperoleh melalui wawancara dengan calon debitur, kunjungan ko lokasi calon debitur dan penyelidikan tentang tujuan penggunaan kredit.

d. Melakukan analisa dan evaluasi terhadap prinsip $5 \mathrm{C}$ calon debitur(Yasman \& Afriyeni, 2015), yaitu:

1) Watak (Character)

Bertujuan untuk mendapatkan gambaran akan prilaku calon debitur sebelum dan selama permohonan kredit dilakukan.

2) Kemampuan (Capacity)

Merupakan gambaran kemampuan calon debitur untuk memenuhi kewajiban-kewajibannya.

3) Modal (Capital)

Bertujuan untuk melihat kemampuan debitur dalam menyediaakan modal sendiri. Dalam hal ini PT. BPR Cempaka Mitra Nagari Padang mensyaratkan $10 \%$ modal sendiri dari keseluruhan dana yang dibutuhkan. 
4) Kondisi Ekonomi (Condition Of Economic)

Dalam menganalisa Condition Of Economic PT. BPR Cempaka Mitra Nagari Padang akan melihat kondisi perusahaan sekarang maupun yang akan datang sesuai dengan perkembangan usaha, jenis usaha yang dilaksanakan.

5) Agunan (Collateral)

Menyangkut nilai harta yang dijamin oleh calon debitur sebagai jaminan atas kredit yang diajukan kepada PT. BPR Cempaka Mitra Nagari Padang mensyaratkan kepada calon debitur untuk menyediakan jaminan sebesar $60 \%$ dari jumlah kredit yang diajukan. Adapun bentuk jaminan dapat berupa sertifikat tanah, mobil/kendaraan bermotor dan hak sewa toko.

e. Rekomendasi kredit oleh Account Officer secara tertulis. Isi dari rekomendasi tersebut adalah :

1) Tujuan penggunaan kredit

Penggunaan kredit harus sesuai dengan bidang usaha debitur, berdasarkan target produktivitas yang akan dicapainya. Adapun pemberian kredit padaPT. BPR Cempaka Mitra Nagari Padang digunakan untuk usaha debitur dalam bidang usaha pertanian, perindustrian, perdagangan dan jasa lainnya.

2) Plafond Kredit

Jumlah kredit yang diberikan PT. BPR Cempaka Mitra Nagari Padang kepada debitur yang menerima kredit.

3) Jangka waktu krdit Jangka waktu yang diberikan oleh PT. BPR Cempaka Mitra Nagari Padang kepada debitur yang menerima kredit.

4) Jenis kredit yang diajukan

Jenis-jenis kredit PT. BPR Cempaka Mitra Nagari Padang ini adalah Kredit Investasi, Kredit Modal Kerja dan Kredit Konsumsi.

5) Bunga yang harus dibayar

Ketentuan pembayaran bunga pada PT. BPR Cempaka Mitra Nagari Padang adalah :

a. Cara Perhitungan :

1) Bunga Flat yaitu bunga yang berdasarkan kepada limit selamajangka waktu kredit.

2) Bunga Annuitas yaitu bunga yang perhitungannya berdasarkan bukti debet harian dan besarnya angsuran perbulan (pokok dan bunga).

3) Bunga Efektif yaitu perhitungan bunga yang berdasarkan pada bukti debet harian yang dikalikan dengan bunga yang berlaku.

b. Jenis Bunga

Bunga dihitung 30 hari dalam sebulan atau 360 hari dalam setahun. 
Jenis - jenis Bunga :

1) Fixed Rate yaitu suku bunga yang dikenakan secara tetap selama jangka waktu kredit.

2) Floating Rate yaitu suku bunga yang dikenakan secara mengambang artinya sewaktu-waktu dapat berubah sesuai dengan perkembangan bunga yang berlaku dipasaran.

6) Provisi Kredit

Merupakan beban yang dikenakan kepada debitur sebagai akibat dari perjanjian kredit yang dibuat.

7) Agunan

Agunan harus dikemukakan secara teperinci, antara lain jumlah jaminan, nilai jaminan dan statusbpemiliknya. Adapun bentuk jaminan dapat berupa sertifikat tanah, mobil/kendaran bermotor dan hak sewa toko.

8) Asuransi Kredit

Setiap pemberian kredit kepada debitur selalu diasuransikan oleh pihak PT. BPR Cempaka Mitra Nagari Padang agar dapat dikuranginya resiko bilamana terjadi hal-hal yang tidak diinginkan.

9) Administrasi lainnya.

f. Keputusan terhadap PT. BPR Cempaka Mitra Nagari Padang berada di tangan direksi dengan memperhatikan rekomendasi dari Account Officer dan analisa bagian pemasaran dari penilaian kredit.

g. Setelah kredit disetujui PT. BPR Cempaka Mitra Nagari Padang menugaskan debitur untuk menandatangani surat persetujuan membuka kredit (PMK), surat kuasa, surat penyerahan hak milik atas dasar kepercayaan (FEO), kwitansi penarikan kredit, kartu cicilan kredit dan lain-lain oleh bagian kredit. Apabila kredit tidak disetujui maka akan diberitahukan kepada nasabah.

h. Pencairan kredit dapat dilakukan dengan membuka rekening tabungan pada PT. BPR Cempaka Mitra Nagari Padang agar dapat melakukan pendebetan ke rekening tabungan debitur.

Untuk melihat perkembangan jumlah kredit yang diberikan kepada masyarakat dapat dilihat pada tabel 2 :

\section{Tabel 2}

Perkembangan Penyaluran Dana Pada

PT. BPRCempaka Mitra Nagari Padang

Tahun 2014-2018(Dalam Ribuan)

\begin{tabular}{|c|c|c|}
\hline Tahun & Jumlah Kredit & Pertumbuhan Kredit \\
\hline 2014 & $\mathbf{8 . 9 9 3 . 2 5 6}$ & - \\
\hline 2015 & $\mathbf{6 . 2 1 0 . 4 6 4}$ & 30,94 \\
\hline 2016 & $\mathbf{5 . 2 2 6 . 7 7 3}$ & $(15,83)$ \\
\hline 2017 & $\mathbf{5 . 1 9 0 . 3 2 3}$ & $(0,69)$ \\
\hline 2018 & $\mathbf{5 . 1 5 3 . 3 2 1}$ & $(1,68)$ \\
\hline
\end{tabular}

Sumber :PT. BPR Cempaka Mitra Nagari Padang

Berdasarkan tabel 2 perkembanga jumlah kredit yang di salurkan PT.BPR Cempaka Mitra Nagari Padang dari tahun 2014 
sapai 2018 penurunan sebesar Rp.3.839.935,- yang berarti menurunnya dana masyarakat dalam bentuk kredit, disebabkan oleh lemahnya pembinaan nasabah oleh bank dilapangan dalam proses permintaan kredit dari calon nasabah sehinga mempersempit peluang debitur untuk melakukan etikat baiknya, oleh sebab itu petugas bank harus mampu membaca situasi dalam memberikan peningkatan minat masyarakat yang membutuhkan dana dalam bentuk kredit untuk memperluas ruang lingkup usahanya agar berkembang lebih pesat dan hal ini merupakan peluang yang baik bagi PT.BPR Cempaka Mitra Nagari Padang.

Dari data-data diatas maka dapat disimpulkan rata-rata perubahan perkembangan penyaluran dana kredit pada tahun 2015 menurun sebesar 30.94\% pada tahun 2016 sebesar 15,83\% dan tahun 2017 sebesar 0,69\%kemudian pada tahun 2018 sebesar 0,71\%.

\section{Jasa-jasa PT. BPR Cempaka Mitra Nagari Padang adalah :}

Jasa-jasa yang diberikan oleh PT. BPR Cempaka Mitra Nagari Padang kepada masyarakat seperti Transfer, Pembayaran BPJS, Pembayaran tagihan listrik (PLN) dan pembayaran tagihan telepon, pembayaran PDAM serta pulsa prabayar.

2. Masalah-Masalah Yang Dihadapi Dalam Penghimpunan Dana dan Penyaluran Kredit Serta Cara Penanggulangannya

Dalam penghimpunan dana dan penyaluran kredit tidaklah selalu berjalan dengan lancar seperti yang diharapkan. Seringkali terjadi kendalakendala atau permasalahan baik berasal dari pihak calon nasabah, pihak nasabah ataupun pihak bank itu sendiri. Adapun masalah-masalah yang dihadapi PT. BPR Cempaka Mitra Nagari Padang antara lain :

1. Dari Calon Nasabah

a. Masih kurangnya pengetahuan masyarakat mengenai dunia perbankan.

b. Seringkali calon nasabah memberikan informasi yang tidak benar, sehingga mengakibatkan pihak bank harus menganalisa kembali maupun mendata ulang informasi yang diberikan calon nasabah.

c. Seringkali clon nasabah yang mengajukan permohonan tidak memiliki pembukuan, keterangan dan catatan yang lengkap mengenai usahanya, sehingga menyulitkan pihak bank untuk menilai secara akurat tentang usahanya.

2. Dari Nasabah Sendiri

a. Kredit yang digunakan sering disalahgunakan atau keluar dari tujuan kredit semula.

b. Kurangnya keterampilan nasabah dalam memanage usahanya sehingga cenderung rugi.

c. Adanya niat kurang baik dari debitur sendiri untuk tidak melakukan pembayaran pinjaman kreditnya.

d. Keadaan ekonomi yang mengakibatkan pasar lemah sehingga nasabah yang usahanya berdagang juga mengalami kelesuan. Dan sudah tentu kredit yang diberikan oleh bank akan macet pengembaliannya, maka dari 
itulah bank juga perlu memberikan bimbingan kepada nasabah kecil tersebut.

e. Nasabah mengalami musibah seperti meninggal dunia, sakit-sakitan serta usaha mengalami bencana alam, kebakaran, banjir, dan lain-lain sementara bank tidak memiliki asuransi atas usahanya.

Adapun kebijaksanaan yang diambil PT. BPR Cempaka Mitra Nagari

Padang dalam mengatasi masalah-masalah tersebut antara lain:

1. PT. BPR Cempaka Mitra Nagari Padang menyebarkan brosur yang emnginformasikan tentang perbankan khusunya tentang PT. BPR Cempaka Mitra Nagari Padang.

2. Mengadakan penyuluhan-penyuluhan yang dilakukan oleh pegawai bank yang telah dibina. Adapun penyuluhan ini dilakukan di forum kemasyarakatan.

3. Apabila usaha nasabah mnegalami kemacetan sehingga nasabah tidak mampu membayar angsuran kreditnya selama tiga bulan berturut-turut, maka PT. BPR Cempaka Mitra Nagari Padang membantu nasabah dengan cara :

a. Penjualan agunan

Penjualan agunan atau asset perusahaan yang dilakukan secara sukarela dalam rangka penyelesaian kredit.

b. Pengambilan asset debitur oleh bank

Srategi ini digunakan dalam rangka penyelesaian kredit dengan cara mengkompensasikan seluruh hutang debitur dengan atau tanpa keringanan.

c. Keringanan tunggakan pokok

Upaya penyelesaian kredit dengan melalui pemberian keringanan hutang pokok kepada debitur yang akan melunasi hutangnya sekaligus.

d. Likuidasi

Yaitu dengan mengambil kekayaan debitur yang tidak ada hubungannya dengan kegiatan usaha yang dilakukan oleh debitur dank bank dapat melelangnya.

4. Pelaksanaan pengawasan yang disertai dengan pembinaan nasabah harus dijalankan, serta para pejabat yang mempunyai dedikasi yang tinggi terhadap pekerjaannya dan juga mempunyai rasa tanggung jawab dan daya intelegensi yang tinggi. Dalam beberapa kali pendekatan, apalagi didahului dengan tidak lancarnya kredit, pejabat yang bersangkutan harus mampu membuat sesuatu perkiraan yang menjurus untuk mengetahui latar belakang ketidaklancaran kredit tersebut.

5. Memberikan informasi yang benar bahwa agunan/jaminan yang diberikan debitur tidak mutlak menjadi hak bank bila debitur melunasi kreditnya sehingga tidak ada ketakutan masyarakat untuk mengajukan permohonan kredit dan masyarakat pun berusaha untuk melunasi angsuran kreditnya.

Berdasarkan data diatas dapat dijelaskan bahwa Aktivitas Pemasaran Produk Bank yang dilakukan oleh manajemen PT. BPR Cempaka Mitra Nagari Padang sebagai berikut : 
PT. BPR Cempaka Mitra Nagari adalah suatu lembaga keuangan yang bergerak di bidang perbankan. Produk-produk yang di pasarkan dalam rangka kegiatan operasional bank yaitu berupa penghimpunan dana dalam bentuk tabungan terdiri dari tabungan cempaka, tabungan mitra nagari, tabungan qurban, tabungan pionir (tabungan plajar), simpanan pelajar (simple), simpanan bajapuik serta deposito. PT. BPR Cempaka Mitra Nagari Padang juga melakukan penyaluran dana dalam bentuk kredit investasi, kredit modal kerja dan kredit konsumsi.

Rata-rata perubahan perkembangan penyaluran dana kredit yang terjadi pada PT. BPR Cempaka Mitra Nagari Padang mengalami penurunan setiap tahunnya, dimana dapat dilihat pada tahun 2015 pertumbuhan kredit bank sebesar $30.94 \%$, dan pada tahun-tahun berikutnya tingkat pertumbuhan kredit bank selalu mengalami penurunan seperti tahun 2016 sebesar 15,83\% dan tahun 2017 sebesar 0,69\% kemudian pada tahun 2018 sebesar 1,68\%.

\section{SIMPULAN}

Berdasarkan uraian yang telah dikembangkan pada bab-bab terdahulu, maka penulis dapat menyampaikan beberapa kesimpulan mengenai aktifa pemasran produk bank yank dilakukan oleh PT. BPR Cempaka Mitra Nagari, yaitu sebagai berikut :

PT. BPR Cempaka Mitra Nagari adalah suatu lembaga keuangan yang bergerak di bidang perbankan. Produk-produk yang di pasarkan dalam rangka kegiatan operasional bank yaitu berupa penghimpunan dana dalam bentuk tabungan terdiri dari tabungan cempaka, tabungan mitra nagari, tabungan qurban, tabungan pionir (tabungan plajar), simpanan pelajar (simple), simpanan bajapuik serta deposito. PT. BPR Cempaka Mitra Nagari Padang juga melakukan penyaluran dana dalam bentuk kredit investasi, kredit modal kerja dan kredit konsumsi.

Agar aktivitas pemasaran yang dilakukan dapat terencana dan terarah maka PT. BPR Cempaka Mitra Nagari menerapkan kebijaksanaan bauran pemasaran dengan cara menciptakan produk simpanan dengan kualitas yang baik, kemudahan-kemudahan untuk mendapat produk tersebut, menetapkan tingkat suku bunga sesuai dengan ketentuan yang berlaku, tempat operasional yang strategis, mengunakan karyawan yang mempunyai rasa loyalitas yang tinggi dan berpotensi dibidangnya serta memberikan pelayanan yang ramah dan baik. Bauran pemasaran dari PT. BPR Cempaka Mitra Nagari secara garis besar adalah :

a. Produk-produk yang dipasarkan dalam rangka kegiatan operasional bank yaitu berupa penghimpunan dana dalam bentuk tabungan terdiri dari tabunan cempaka, tabunga mitra nagari, tabungan qurban, tabungan pionir (tabunga pelajar), tabungan simple (simpanan pelajar), simpanan bajapuik serta deposito PT. BPR Cempaka Mitra Nagari juga melakukan penyaluran dana dalam bentuk kredit investasi, kredit modal kerja dan kredit konsumsi.

b. Harga, dengan menetapkan suku bunga tabungan 2,00\% sampai 4,00\% pertahun dan suku bunga deposito sebesar 7,50\% sampai $8,75 \%$ pertahun. Sedangkan suku bunga kredit ditetapkan berdasarkan jumlah tabungan, yakni sebesar : 
1) Untuk pinjaman Rp. 1.000.000,- s/d Rp. 25.000.000,- = 22\%/th.

2) Untuk pinjaman $>$ Rp. $25.000 .000,-\mathrm{s} / \mathrm{d}$ Rp. $50.000 .000,-=21 \% /$ th.

3) Untuk pinjaman > Rp. 50.000.000,- $=19 \% /$ th.

c. Lokasi, PT. BPR Cempaka mitra Nagari di jalan andalas No. 2G Simpang Haru Padang. Lokasi kantor PT. BPR Cempaka Mitra Nagari yang terletak berdekatan degan pasar, sekolah, perumahan penduduk, instansi pemerintah dan perdagangan.

d. Promosi, PT.BPR Cempaka Mitra Nagari mengenalkan produknya melalui periklanan, kegiatan promosi penjualan, publisitas dan penjualan pribadi dengan perusahaan untuk menarik calon nasabah yang baru dan mempertahankan yang lama.

e. Karyawan, PT. BPR Cempaka Mitra Nagari Padang mempuyai tingkat pendidikan yang berbeda-beda mulai dari SMU sampai sarjana.

f. Proses, merupakan aktivitas yang teriri dari prosedur penghimpunan dana dan penyaluran dana, serta aktivitas pegawai/karyawan PR. BPR Cempaka Mitra Ngari Padang.

\section{UCAPAN TERIMA KASIH}

Terimakasih penulis sampaikan kepada :

1. Kedua Orang Tua yang senantiasa memberikan dukungan baik secara moril maupun materil.

2. Direktur AKBP beserta prodi AKBP yang telah memberikan kesempatan kepada penulis untuk melakukan penelitian ini.

3. Dosen Pembimbing tugas akhir yang telah memberikan arahan dan bimbingan hingga tugas akhir ini bisa terselesaikan.

4. Pimpinan PT. BPR Cempaka Mitra Nagari Padang yang telah mengizinkan penulis dalam memperoleh informasi beserta pengambilan data.

5. Semua Pihak yang telah memberikan dukungan dan bantuannya dalam penyelesaian tugas akhir ini.

\section{DAFTAR PUSTAKA}

Chasanah, H. C. (2016). Pengaruh kredit macet dan penyaluran kredit terhadap profitabilitas perbankan (studi pada pt. bank rakyat indonesia (persero) tbk kanca blitar).

Fernandes, Y. D., \& Marlius, D. (2018). Peranan Customer Service Dalam Meningkatkan Pelayanan Kepada Nasabah Pada PT. Bank Pembangunan Daerah Sumatera Barat Cabang Utama Padang. https://doi.org/10.31227/osf.io/wrh3p

Hidayati, R. R., \& Marlius, D. (2018). Aktivitas Promosi Dalam Meningkatkan Dana Pihak Ketiga Pada PT. Bank Perkreditan Rakyat (BPR) Batang Kapas Pesisir Selatan. https://doi.org/10.31227/osf.io/8dgqn 
Marlius, D. (2016). Pengaruh Bauran Pemasaran Jasa Terhadap Minat Nasabah Dalam Menabung Pada Bank Nagari Cabang Muaralabuh. https://doi.org/10.31227/osf.io/vdqgx

Safitri, R. N., \& Marlius, D. (2017). Penerapan E-Banking Dalam Meningkatkan Jasa Dan Layanan Perbankan Di PT. Bank Rakyat Indonesia Cabang Padang. https://doi.org/10.31227/osf.io/gkv8t

Sinuhaji, E. (2010). Penerapan Layanan Unggul Dalam Pemasaran Produk Bank. Jurnal Mediasi, 2(1), 1-8.

Susanti, F. W Ekazaputri. (2018). Service Performance Dan Kepuasan Sebagai Moderating Variabel Terhadap Loyalitas Nasabah Pada PT BPR Labuh Gunung Payakumbuh Jurnal Benefita: Ekonomi Pembangunan Manajemen Bisnis Dan Akuntansi. Volume 3. No. 3. Hal. 433444.http://doi.org/10.22216/jbe.v3i3.3472

Undang-Undang RI No.10. (1998). Undang-Undang Republik Indonesia No.10 Tahun 1998 Tentang Perubahan Atas Undang-Undang No.7 Tahun 1992 Tentang Perbankan.

Widayati, R. (2019). Upaya Meningkatkan Nasabah Tabungan Melalui Tabungan Bajapuik Pada PT. Bank Perkreditan Rakyat (BPR) Jorong Kampuang Tangah (JKT) Pariaman. https://doi.org/10.17605/OSF.IO/36M48

Widayati, R. (2019). Aktivitas Pemasaran Produk Simpanan PT. Bank Tabungan Negara (Persero)Tbk Kantor Cabang Padang. https://doi.org/10.17605/OSF.IO/3Z5YC

Widayati, R. (2019). Promotional Activities And Services Bank Nagari Kambang Increase In Customer. https://doi.org/10.17605/OSF.IO/MYAVT

Widayati, R. (2019). Upaya Meningkatkan Minat Untuk Menabung Pada PT. BPR Batang Kapas. https://doi.org/10.17605/OSF.IO/AEVW7

Yasman, R., \& Afriyeni, A. (2015). Prosedur Pemberian Kredit Pada PT. Bank Perkreditan Rakyat (BPR) Jorong Kampung Tangah (JKT) Pariaman Cabang Padang. Akademi Keuangan Dan Perbankan, (7), 1-9. 